\title{
Abraham Model Descriptors for Melatonin; Prediction of Solution, Biological and Thermodynamic Properties
}

\author{
Xiangli Liu ${ }^{1} \cdot$ Michael H. Abraham² William E. Acree Jr $^{3}$
}

Received: 5 July 2021 / Accepted: 1 September 2021 / Published online: 27 January 2022

(c) The Author(s) 2022

\begin{abstract}
Literature solubilities have been used to obtain properties or descriptors of melatonin. These indicate the chemical nature of melatonin: it is dipolar and has moderate hydrogen bond acidity and hydrogen bond basicity. The descriptors can be combined with equations that we have previously constructed to estimate water-solvent partition coefficients and solubilities in a huge number of organic solvents. In the same way, a range of biological properties can be estimated. These include blood-tissue partitions, water-skin partition and permeability through skin.
\end{abstract}

Keywords Melatonin · Hydrogen bonding · Solubilities · Linear free energy relationships · Biological properties

\section{Introduction}

Melatonin (CAS 73-31-4) is a natural hormone found in plants and animals, world-wide. In humans and animals it controls the sleep-wake circadian rhythm, and functions as an antioxidant and in plants it is involved in growth and in photosynthesis. The structure of melatonin is shown in Fig. 1. Melatonin supplements are widely used to combat sleep disorders. Surprisingly, in spite of its wide occurrence and use, there is still a lack of basic physicochemical and biological properties of melatonin. It is the purpose of this work to use recently determined solubilities of melatonin [1-3] to obtain Abraham descriptors, and then to use these descriptors to deduce a large number of physicochemical and biological properties.

Xiangli Liu

X.Liu18@bradford.ac.uk

1 School of Pharmacy and Medical Sciences, Faculty of Life Sciences, University of Bradford, Bradford BD7 1DP, UK

2 Department of Chemistry, University College London, 20 Gordon Street, WC1H OAJ London, UK

3 Department of Chemistry, University of North Texas, 1155 Union Circle Drive \#305070, Denton, TX 76203-5017, USA 
Fig. 1 The structure of melatonin

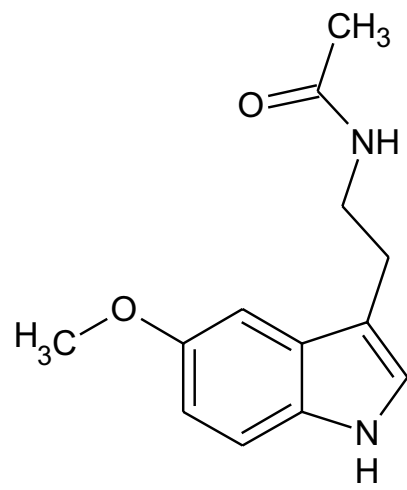

\section{Methods}

We have previously used water-solvent partition coefficients and solubilities of compounds in water and organic solvents to obtain properties or descriptors of compounds [4-9]. The method relies on two general linear free energy relationships, Eqs. 1 and 2, that are used to correlate the transfer of neutral solutes from water to organic solvents and from the gas phase to organic solvents. The dependent variable in Eq. 1 is $\log _{10} P$, where $P$ is the molar water to solvent partition coefficient for a series of solutes, and in Eq. 2 it is $\log _{10} K$ where $K$ is the dimensionless gas phase to solvent partition coefficient for a series of solutes.

$$
\begin{gathered}
\log _{10} P=c+e E+s S+a A+b B+v V \\
\log _{10} K=c+e E+s S+a A+b B+l L
\end{gathered}
$$

In Eqs. 1 and 2 the independent variables, or descriptors, are properties of the neutral solutes as follows [4-9]. $E$ is the solute excess molar refraction in $\mathrm{cm}^{3} \cdot \mathrm{mol}^{-1 / 10, S}$ is the solute dipolarity/polarizability, $A$ is the overall solute hydrogen bond acidity, $B$ is the overall solute hydrogen bond basicity, $V$ is McGowan's characteristic molecular volume in $\mathrm{cm}^{3} \cdot \mathrm{mol}^{-1} / 100$ and $L$ is the logarithm of the gas to hexadecane partition coefficient at 298 K. Coefficients in Eqs. 1 and 2 are shown in Table 1 for systems that we have used in the current study.

For pure liquid compounds, $E$ is obtained from the refractive index of the compound at $293 \mathrm{~K}[4,5,9]$ and for gases and solids the refractive index can be estimated or $E$ itself can be calculated quite easily [10,11]. For neutral molecules, the descriptors $S, A$ and $B$ can be obtained from water to solvent partition measurements, and from molar solubilities in nonaqueous sovents, $C_{S}$ [4-9] The latter can be transformed into water-solvent partition coefficients through Eq. 3, where $C_{W}$ is the corresponding molar solubility in water. If $C_{W}$ is not known, it can be allowed to 'float' and become another descriptor to calculate.

$$
P=C_{S} / C_{W} \quad \log _{10} P=\log _{10} C_{S}-\log _{10} C_{W}
$$

$P$ can then be converted into the air-solvent partition coefficient $K$ through Eq. 4.

$$
\log _{10} K-\log _{10} K_{W}=\log _{10} P
$$




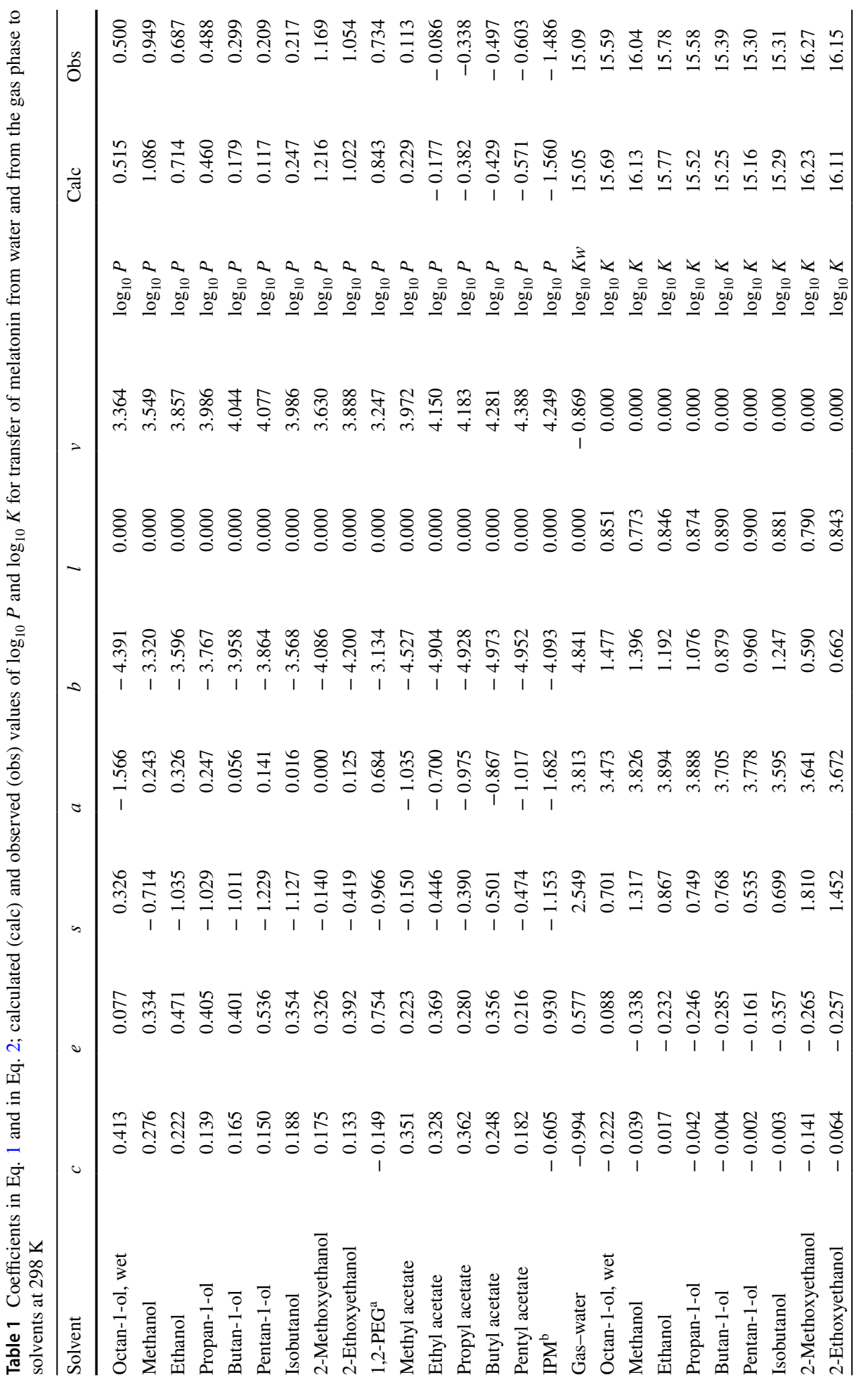




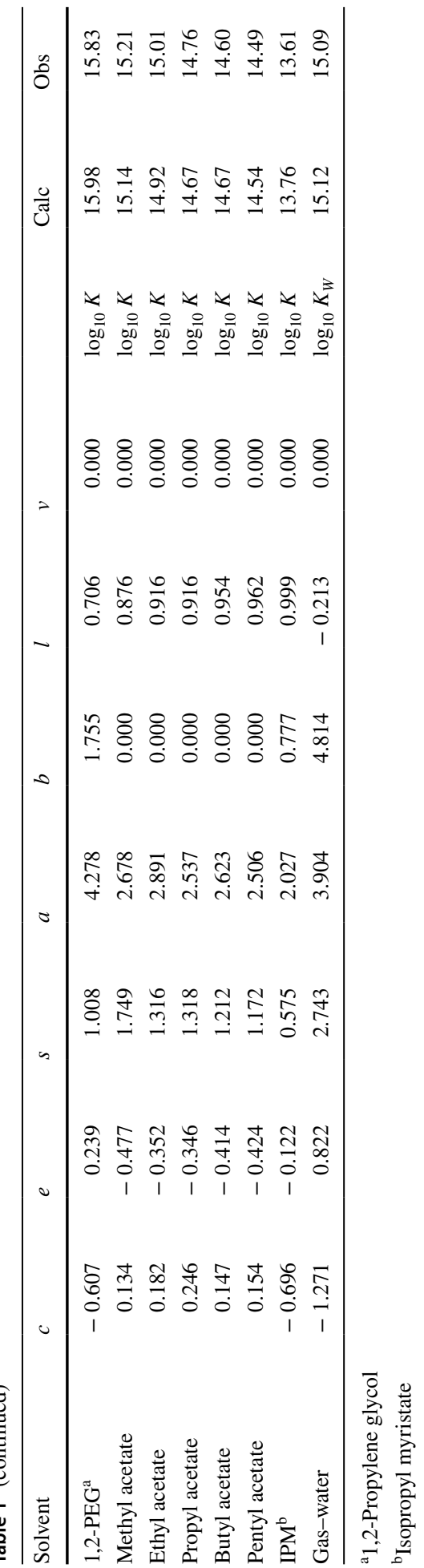


where $K_{W}$ is the dimensionless air to water partition coefficient defined through Eq. 5, where $C_{W}$ and the corresponding gaseous concentration, $C_{G}$, are in units of mol.dm ${ }^{-3} \cdot K_{W}$ is the reciprocal of the Henry's law constant in water, with due regard to units.

$$
K_{W}=C_{W} / C_{G}
$$

\section{Results and Discussion}

We have solubilities of melatonin in fifteen different solvents [1-3], and these can then be converted into fifteen partition coefficients through Eq. 3 provided that a numerical value of $\log _{10}$ $C_{W}$ is known. In instances where $\log _{10} C_{W}$ and $\log _{10} K_{W}$ are not available, they can be calculated as part of the regression analysis from measured solubility data for melatonin dissolved in several organic solvents. That will be the case in the current study. The corresponding values of the gas-solvent partition coefficients can then be obtained through Eq. 5. Finally, all the $\log _{10} P$ values yield air-solvent partition coefficients through Eq. 4 . We also have a directly determined water-(wet) octanol partition coefficient [12], and two equations in $\log _{10} K_{W}$, making a total of 34 equations, see Table 1 . $E$ was obtained from a calculated refractive index [13], as 1.60 and $V$ was calculated as $1.8251[3,10,11]$. We then have the descriptors $S, A, B, L$, $\log _{10} K_{W}$ and $\log _{10} C_{W}$ to obtain from a set of 34 simultaneous equations. The set was solved by trial-and-error to yield the descriptors in Table 2 with a standard deviation, $S D$ between observed and back-calculated dependent variables of only $0.084 \log _{10}$ units. The dependent variables $\left(\log _{10} P\right.$ or $\left.\log _{10} K\right)$ are listed in Table 1. The calculation procedure is identical to that used in determining the solute descriptors of telmisartan [14], xanthone [15], $o$-acetoacetanisidide [16], 1,3,5-trinitrobenzene [17], caprolactam [7], levetiracetam [18] and other crystalline nonelectrolyte organic compounds. In each of the afore-mentioned instances the numerical values of $\log _{10} C_{W}$ and $\log _{10} K_{W}$ were determined as part of the regression analysis.

The descriptors for melatonin are not exceptional. The compound is dipolar $(S=2.46)$ as expected from its structure, Fig. 1, and it has quite a large hydrogen-bond acidity $(A=0.95)$ due to the amide-NH and the indole-NH hydrogen atoms. Once the descriptors for melatonin have been determined, they can be used in a very large number of equations on the lines of Eq. 1 to calculate partition coefficients from water to some 100 wet solvents, 100 dry solvents and 90 ionic liquids [19]. Then with $\log _{10} C_{W}=-1.099$, the corresponding solubilities can be obtained through Eq. 3. This seems to be the first time that any general method for calculation of partition coefficients and solubilities of melatonin has been developed.

Because of the use of melatonin supplements, it is of some importance to use our descriptors to calculate biological properties of melatonin. We give in Table 3, coefficients in Eq. 1 for a number of blood-tissue distributions at $313 \mathrm{~K}$ [20, 21], and for water-skin partition coefficients and permeability coefficients, again at $313 \mathrm{~K}$ [20]. In addition to predicting molar solubilities and blood to tissue distribution coefficients we can calculate the vapor pressure [22], standard molar enthalpies of vaporization [23] and sublimation [24] at $298.15 \mathrm{~K}$, enthalpies of solvation of solvation in 30 different organic solvents [25-29], limiting diffusion coefficients in water and in seven organic

Table 2 Descriptors for melatonin obtained by solution of the set of 34 simultaneous equations

\begin{tabular}{llllllll}
\hline$E$ & $S$ & $A$ & $B$ & $V$ & $L$ & $\log _{10} K_{W}$ & $\log _{10} C_{W}$ \\
\hline 1.60 & 2.46 & 0.95 & 1.41 & 1.8251 & 10.189 & 15.09 & -1.099 \\
\hline
\end{tabular}


Table 3 Equations for distribution from blood to tissues and from water to human skin, and skin permeability all at $313 \mathrm{~K}$; calculated values for melatonin

\begin{tabular}{lrrrrrrr}
\hline System & \multicolumn{1}{l}{$c$} & \multicolumn{1}{l}{$a$} & \multicolumn{1}{l}{$l$} & \multicolumn{1}{l}{$l$} & \multicolumn{1}{c}{ Calc $^{\mathrm{a}}$} \\
\hline Blood-brain & 0.547 & 0.221 & -0.604 & -0.641 & -0.681 & 0.635 & -0.995 \\
Blood-muscle & 0.082 & -0.059 & 0.010 & -0.248 & 0.028 & 0.110 & 0.017 \\
Blood-liver & 0.292 & 0.000 & -0.296 & -0.334 & 0.181 & 0.337 & 0.117 \\
Blood-lung & 0.269 & 0.000 & -0.523 & -0.723 & 0.000 & 0.720 & -0.390 \\
Blood-kidney & 0.494 & -0.067 & -0.426 & -0.367 & 0.232 & 0.410 & 0.066 \\
Blood-heart & 0.132 & -0.039 & -0.394 & -0.376 & 0.009 & 0.527 & -0.282 \\
Blood-skin & -0.105 & -0.117 & 0.034 & 0.000 & -0.681 & 0.756 & 0.211 \\
Blood-fat & 0.077 & 0.249 & -0.215 & -0.902 & -1.523 & 1.234 & -0.806 \\
Water-skin & 0.523 & 0.101 & -0.076 & -0.022 & -1.951 & 1.652 & 0.741 \\
$\log _{10} K p^{\mathrm{b}}$ & -5.420 & -0.102 & -0.457 & -0.324 & -2.608 & 2.066 & -6.922 \\
\hline
\end{tabular}

${ }^{\mathrm{a} C a l c u l a t e d ~ v a l u e s}$

${ }^{\mathrm{b}}$ Water skin permeation, as $\log _{10} K p$ with $K p$ in $\mathrm{cm} \cdot \mathrm{s}^{-1}$

solvents [30], and the "baseline" median lethal molar concentrations of melatonin towards several aquatic organisms, including six species of fish [31] and three species of water fleas [32] by substituting the numerical values of the solute descriptors given in Table 2 into our previously published Abraham model correlations. For example, we calculate numerical values of $-158 \mathrm{~kJ} \cdot \mathrm{mol}^{-1}$ and $-132.3 \mathrm{~kJ} \cdot \mathrm{mol}^{-1}$ for the standard molar enthalpies of solvation of melatonin dissolved in pyridine [27] and dichloromethane [32] at $298.15 \mathrm{~K}$, respectively, and the estimated equilibrium vapor pressure, $V P$, above solid melatonin at $298.15 \mathrm{~K}$ [22] is $V P=1.8 \times 10^{-18}$ atm. We were unable to find measured experimental values for melatonin for the fore-mentioned blood to tissue distribution coefficients, aquatic toxicities, and physical and thermodynamic properties in the published literature.

\section{Conclusions}

We have shown that properties, or descriptors, of melatonin can be obtained from molar solubilities in organic solvents. These properties then describe the chemical nature of melatonin, such as dipolarity and hydrogen-bond acidity and basicity. They can be used, together with equations that we have constructed previously, to predict a huge number of physicochemical properties. In view of the use of melatonin supplements, the prediction of biological properties of melatonin is of considerable importance, and this is what we have been able to do.

\section{Declarations}

Conflict of interest There are no conflicts of interest to declare. 
Open Access This article is licensed under a Creative Commons Attribution 4.0 International License, which permits use, sharing, adaptation, distribution and reproduction in any medium or format, as long as you give appropriate credit to the original author(s) and the source, provide a link to the Creative Commons licence, and indicate if changes were made. The images or other third party material in this article are included in the article's Creative Commons licence, unless indicated otherwise in a credit line to the material. If material is not included in the article's Creative Commons licence and your intended use is not permitted by statutory regulation or exceeds the permitted use, you will need to obtain permission directly from the copyright holder. To view a copy of this licence, visit http://creativecommons.org/licenses/by/4.0/.

\section{References}

1. Kikwai, L., Kanikkannan, N., Babu, R.J., Singh, M.: Effect of vehicles on the transdermal delivery of melatonin across porcine skin in vitro. J. Cont. Release 83, 307-311 (2002)

2. Sun, R., Wang, Y., He, H., Wan, Y., Li, L., Sha, J., Jiang, G., Li, Y., Li, T., Ren, B.: Solubility measurement, solubility behavior analysis and thermodynamic modelling of melatonin in twelve pure solvents from 278.15 K to 323.15 K. J. Mol. Liq. 319, 114139/1-114139/12 (2020)

3. Sun, R., He, H., Wan, Y., Wang, Y., Li, L., Sha, J., Jiang, G., Li, Y., Li, T., Ren, B.: Solubility of melatonin in ethyl acetate $+(N, N$-dimethylformamide, 2-methoxyethanol, 2-ethoxyethanol and methanol): determination, correlation, thermodynamic properties and Hansen solubility parameters at saturation. J. Chem. Thermodyn. 156, 106372/1-106372/14 (2021)

4. Abraham, M.H.: Scales of hydrogen bonding: their construction and application to physicochemical and biochemical processes. Chem. Soc. Rev. 22, 73-83 (1993)

5. Abraham, M.H., Ibrahim, A., Zissimos, A.M.: The determination of sets of solute descriptors from chromatographic measurements. J. Chromatogr. A 1037, 29-47 (2004)

6. Abraham, M.H., Smith, R.E., Luchtefeld, R., Boorem, A.J., Luo, R., Acree, W.E. Jr.: Prediction of solubility of drugs and other compounds in organic solvents. J. Pharm. Sci. 99, 1500-1515 (2010)

7. Abraham, M.H., Acree, W.E. Jr., Brumfield, M., Hart, E., Pipersburgh, L., Mateja, K., Dai, C., Grover, D.I., Zhang, S.: The deduction of physicochemical properties from solubilities; 2,4-dihydroxybenzophenone, biotin and caprolactam as examples. J. Chem. Eng. Data 60, 1440-1446 (2015)

8. Poole, C.F., Ariyasena, T.C., Lenca, N.: Estimation of the environmental properties of compounds from chromatographic properties and the solvation parameter method. J. Chromatogr. A 1317, 85-104 (2013)

9. Clarke, E.D., Mallon, L.: The determination of Abraham descriptors and their application to crop protection research. In: Jeschke, P., Krämer, W., Schirmer, U., Witschel, M. (eds.) Modern Methods in Crop Protection Research. Wiley-VCH Verlag GmbH \& Co (2012)

10. Ulrich, N., Endo, S., Brown, T.N., Watanabe, N., Bronner, G., Abraham, M.H., Goss, K.-U.: UFZLSER database v 3.2.1 [Internet], Leipzig, Germany, Helmholtz Centre for Environmental ResearchUFZ. 2017. http://www.ufz.de/lserd

11. ADME, version 5.0, Advanced Chemistry Development, Toronto

12. BioLoom, BioByte Corp, Claremont

13. ChemSketch, A.C.: Development, 110 Yonge Street, 14th Floor, Toronto

14. Acree, W.E., Jr., Horton, M.Y., Higgins, E., Abraham, M.H.: Commentary on measurement and correlation of the solubility of telmisartan (form A) in nine different solvents from 277.85 to $338.35 \mathrm{~K}$. J. Solution Chem. 45, 1902-1905 (2016)

15. Qian, E., Lee, G., Che, M., Wang, L., Yue, D., Fischer, R., Jodray, M., Gupta, A., Neal, R., Liu, Y., Acree, W.E. Jr., Abraham, M.H.: Determination of Abraham model solute descriptors for xanthone based on experimental solubility measurements at 298.2 K. Phys. Chem. Liq. 58, 214-221 (2021)

16. Lee, G., Che, M., Qian, E., Wang, L., Gupta, A., Neal, R., Yue, D., Downs, S., Mayes, T., Rose, O., Acree, W.E. Jr., Abraham, M.H.: Determination of Abraham model solute descriptors for $o$-acetoacetanisidide based on experimental solubility data in organic mono-solvents. Phys. Chem. Liq. 57, 528535 (2019)

17. Abraham, M.H., Acree, W.E. Jr., Liu, X.: Descriptors for high-energy nitro compounds; estimation of thermodynamic, physicochemical and environmental properties. Propellants Explos. Pyrotech. 46, 267-279 (2021)

18. Yue, D., Acree, W.E. Jr., Abraham, M.H.: Applications of Abraham solvation parameter model: estimation of the lethal median molar concentration of the antiepileptic drug levetiracetam towards aquatic organisms from measured solubility data. Phys. Chem. Liq. 58, 302-308 (2020) 
19. Liu, X., Abraham, M.H., Acree, W.E., Jr.: Descriptors for vitamin K3 (menadione); calculation of biological and physicochemical properties. J. Mol. Liq. 330(1-115707/4), 115707 (2021)

20. Abraham, M.H., Gola, J.M.R., Ibrahim, A., Acree, W.E. Jr., Liu, X.: The prediction of blood-tissue partitions, water-skin partitions and skin permeation for agrochemicals. Pest Manag. Sci. 70, 11301137 (2014)

21. Abraham, M.H., Gola, J.M.R., Ibrahim, A., Acree, W.E. Jr., Liu, X.: A simple method for estimating in vitro air-tissue and in vivo blood-tissue partition coefficients. Chemosphere 120, 188-191 (2015)

22. Abraham, M.H., Acree, W.E. Jr.: Estimation of vapor pressures of liquid and solid organic and organometallic compounds at 298.15 K. Fluid Phase Equilib. 519(1-112595/5), 112595 (2020)

23. Churchill, B., Acree, W.E. Jr., Abraham, M.H.: Development of Abraham model expressions for predicting the standard molar enthalpies of vaporization of organic compounds at $298.15 \mathrm{~K}$. Thermochim. Acta 681(1-178372/6), 178372 (2019)

24. Abraham, M.H., Acree, W.E. Jr.: Estimation of enthalpies of sublimation of organic, organometallic and inorganic compounds. Fluid Phase Equilib. 515, 112575/1-112575/5 (2020)

25. Wilson, A., Tian, A., Dabadge, N., Acree, W.E. Jr., Varfolomeev, M.A., Rakipov, I.T., Arkipova, S.M., Abraham, M.H.: Enthalpy of solvation correlations for organic solutes and gases in dichloromethane and 1,4-dioxane. Struct. Chem. 24, 1841-1853 (2013)

26. Stephens, T.W., De La Rosa, N.E., Saifullah, M., Ye, S., Chou, V., Quay, A.N., Acree, W.E. Jr., Abraham, M.H.: Enthalpy of solvation correlations for organic solutes and gases dissolved in 2-propanol, 2-butanol, 2-methyl-1-propanol and ethanol. Thermochim. Acta 523, 214 - 220 (2011)

27. Varfolomeev, M.A., Stolov, M.A., Nagrimanov, R.N., Rakipov, I.T., Acree, W.E. Jr., Abraham, M.H.: Analysis of solute-pyridine intermolecular interactions based on experimental enthalpies of solution and enthalpies of solvation of solutes dissolved in pyridine. Thermochim. Acta 660, 11-17 (2018)

28. Magsumov, T.I., Sedov, I.A., Acree, W.E. Jr.: Development of Abraham model correlations for enthalpies of solvation of solutes dissolved in $N$-methylformamide, 2-pyrrolidone and $N$-methylpyrrolidone. J. Mol. Liq. 323(1-114609/10), 114609 (2021)

29. Stolov, M.A., Zaitseva, K.V., Varfolomeev, M.A., Acree, W.E. Jr.: Enthalpies of solution and enthalpies of solvation of organic solutes in ethylene glycol at $298 \mathrm{~K}$ : prediction and analysis of intermolecular interaction contributions. Thermochim. Acta 648, 91-99 (2017)

30. Abraham, M.H., Acree, W.E. Jr.: Limiting diffusion coefficients for ions and nonelectrolytes in solvents water, methanol, ethanol, propan-1-ol, butan-1-ol, octan-1-ol, propanone and acetonitrile at 298 K, analyzed using Abraham descriptors. J. Solution Chem. 48, 748-757 (2019)

31. Hoover, K.R., Acree, W.E. Jr., Abraham, M.H.: Chemical toxicity correlations for several fish species based on the Abraham solvation parameter model. Chem. Res. Toxicol 18, 1497-1505 (2005)

32. Hoover, K.R., Flanagan, K.B., Acree, W.E. Jr., Abraham, M.H.: Chemical toxicity correlations for several protozoas, bacteria and water fleas based on the Abraham solvation parameter model. J. Environ. Eng. Sci. 6, 165-174 (2007)

Publisher's Note Springer Nature remains neutral with regard to jurisdictional claims in published maps and institutional affiliations. 